\title{
The marketised university and the politics of motherhood
}

\author{
Sarah Amsler ${ }^{a^{*}}$ and Sara C. Motta ${ }^{\mathrm{b}}$ \\ $a^{*}$ School of Education, University of Lincoln, Lincoln, LN6 7TS, United Kingdom \\ +44(0)1522-279-186, samsler@lincoln.ac.uk (corresponding author) \\ ${ }^{b}$ Politics and International Relations, Newcastle Business School, University of Newcastle, \\ Callaghan 2308, Newcastle, NSW Australia +44 (02) 4921 5020, \\ sara.c.motta@newcastle.edu.au
}

PRE-PRINT VERSION ACCEPTED FOR PUBLICATION IN GENDER AND EDUCATION, 2017

\begin{abstract}
In this paper, we offer a critique of neoliberal power from the perspective of the gendered, sexualised, raced and classed politics of motherhood in English universities. By using dialogical autoethnographic methods to examine our own past experiences as full-time employed mother-academics, we demonstrate how feminist academic praxis can not only help make the gendered workings of neoliberal power more visible, but also enable us to nurture and sustain alternative ways of being and working in, against and outside the university. Far from desiring greater inclusion into a system which enshrines repressive logics of productivity and reproduces gendered subjectivities, inequalities, silences and exclusions, we aim to refuse and transgress it by bringing feminist critiques of knowledge, labour and neoliberalism to bear on how we understand our own experiences of motherhood in the academic world.
\end{abstract}

\section{Keywords}

motherhood and academia; feminist methodologies and theories; neoliberal subjectification; time-space logics of neoliberalism; resistance, refusal and transgression

[From journal submission system: Motherhood, Markets, Teachers / Educators, Autoethnography, Higher Education, Workplaces] 


\section{The marketised university and the politics of motherhood}

In this paper, we offer a critique of neoliberal power from the perspective of the gendered, sexualised, raced and classed politics of motherhood in English universities. By using dialogical autoethnographic methods to examine our own past experiences as full-time employed mother-academics, we demonstrate how feminist academic praxis can not only help make the gendered workings of neoliberal power more visible, but also enable us to nurture and sustain alternative ways of being and working in, against and outside the university. Far from desiring greater inclusion into a system which enshrines repressive logics of productivity and reproduces gendered subjectivities, inequalities, silences and exclusions, we aim to refuse and transgress it by bringing feminist critiques of knowledge, labour and neoliberalism to bear on how we understand our own experiences of motherhood in the academic world.

We begin by reviewing existing feminist critiques of motherhood and the academy and explain our methodological and political choice of auto-ethnographic and dialogic methods. We then reflect on our own experiences to discuss how the time and space of the neoliberalised university interact with gendered, raced and classed processes of subjectification. In particular, we explore how 'different gendered performance measurement templates merge historically with the psychological managerial techniques of contemporary capitalism' to produce harmful experiences of denial, 'splitting' humiliation, self-discipline and silencing (Mannevuo 2015, p. 86). We end by sharing how we learned to think, write and be together differently, re-inhabiting the time and space of intellectual work and the multiple subjectivities of academic and mother in ways that help us to refuse 
these oppressive logics and re-orient ourselves towards the creation of more integrated and unruly selves and knowledge practices.

\section{Entering the Debate}

This paper emerged from a concern about the way a public debate about women, research and the audit culture in British universities reproduced dehumanising relations between 'mother' and 'academic' subjectivities. ${ }^{1}$ The question was how 'recognising the impact that pregnancy and maternity can have on productivity' and women's careers should be calculated in the national 'Research Excellence Framework' (Haour 2011). ${ }^{2}$ We became interested in how the answer - permitting women who are taking maternity leave to submit one less piece of work for evalution - constructed care as a professional deficit, and in the desire to discount the messiness of life and its unruly epistemic possibilities for knowledge production. $^{3}$

The act of subtracting motherhood when calculating a woman's professional worth is part of a 'continuing ascendency of "equal opportunities" perspectives' in the university (Phipps 2006, p. 126). Such perspectives fail to acknowledge the everyday material conditions of reproduction and the production (and silencing) of classed, raced and gendered subjectivities. By subordinating the body, intimate relations and ethics of care to logics of abstraction and exclusion, they ultimately negate the existence of the motheracademic subject herself. In this paper, we critique this dominant conceptual framing as a technology of neoliberal subjectification. We argue that its liberal framing does not capture the complex exclusions that women face as a result of our intersecting positionalities within the university, and that it neglects differences, inequalities and relations of power 
amongst women in academic contexts (Amsler 2014; Carver 2005; Turner 2002; Turner et al. 2011; Wolfinger et al. 2008). It thus invisibilises the 'unmentionables' that shape women's experiences in everyday practice and naturalises the violence of neoliberal labour (Mills and Berg 2010; see also Coates and Howson 2014; Hey 2004, p. 39). ${ }^{4}$

As we argue, the 'motherhood question' is a critical lens through which to reconsider what Mills and Berg (2010) call the 'gendered political economy of contemporary academic practice', specifically the gendered politics of labour and knowledge in neoliberalism. Far from desiring the greater inclusion of women into this system of knowledge production and valuation, we suggest that it must be troubled by embodied critiques which are rooted in the multiple experiences of mother-subjects in the university. Such critiques can expose the inhumane and patriarchal nature of disciplinary technologies such as the 'Research Excellence Framework' which have become normalised as methods to evaluate academic labour. This contributes to shattering the "conspiracy of silence that has ensured the perpetuation of...forms of marginalization and exclusion in the university' $(\mathrm{Ng} 1997,137)$.

\section{Mothers in the Academy}

This paper is situated within a significant scholarship that documents women's struggles to enter, work, succeed in and transform education, specifically the 'sacred grove' of the academy (Aisenberg and Harrington 1998). Since the 1970s, as mothers became academics and academics became mothers, many critical theorisations specifically of motherhood and academe have emerged (Acker and Armenti 2004; Aisenberg and Harrington 1998; Carver 2005; Coate and Howson 2014; David 2014; Davidson and Langan 2006; Gilbert 2008; Leonard and Malina 1994; Mannevuo 2015; Munn-Giddings 1998; Raddon 2002). We are mindful that women's presence in this establishment is a hard-won, fragile and relatively 
recent historical accomplishment, and that 'women and gender studies have changed the university, not only by introducing a new multidisciplinary field but also by promoting participatory pedagogies' (Stromquist 2015, p. 360; David 2004). The efforts that have brought us this far should not be diminished. Yet struggles to open the academy to people whose lives do not conform to hegemonic models of the bourgeois, entrepreneurial white, male scholar are ongoing. Despite decades of feminist praxis, there is still a 'global pattern of inequality in higher education systems at the senior levels' (Coate and Howson 2014, pp. 567-68). In 2012, only twelve percent of European Research Council advanced research grants were awarded to women (EU 2012). In the UK, women constitute just under twenty percent of academic professors, with only seventeen black women professors (Shilliam 2015, p. 32; see also Bhopal 2015; Howson, Coate and St. Croix 2015; Phiri 2014). Across the globe, women are less likely to be considered 'excellent' academics and many suffer a sense of 'quiet desperation' about both the limits of their professional possibilities and their ability to speak these experiences within academic spaces (Jaschik 2008; see also Gill 2009; Klocker and Drozdzewski 2012).

Beyond admittance to the 'sacred groves' of the university, many women who are both academics and mothers have discovered they inhabit competing worlds and subjectivities. We are increasingly 'expected to be engaged constantly in researching, writing and publishing in a manner that blurs the boundaries between life inside and outside the ivory tower - but only in one way' (Munn-Giddings 1998, 58). Performing the role of the 'professional' academic often means acting as if these activities are not embodied in concrete lives; in particular acting as if we are not mothers by neglecting to 'clock out of' the academic vocation (Carver 2005; Turner 2002) or becoming psychically attached to 
‘clocking in' (Mannevuo 2015). Our scholar-selves (Zembylas 2003, p. 108) and motherselves are thus divided, and often in struggle.

While there has been some recognition that conditions of academic labour are gendered, classed and raced (Adkins 2015, p. 3; Newman 2013; Reay et al. 2001, 2009), much critique of women in academe and of mothers in particular has been written by the white middle-class women who still comprise the bulk of these ranks (see, e.g., David 2014). Analyses of the gendered dynamics of neoliberalisation thus often present the lived experience of academic labour as a disappointment in the loss of autonomous working conditions to which all gendered subjects in the university are presumed to relate. While some experiences are shared among women who have 'had to rethink their relationship with contemporary academia after they have had children', as illustrated in Mona Mannevuo's study of women academics' affective attachments to their vocation (and thus at times to the 'affective cycles of academic capitalism') (Mannevuo 2015, p. 71), uneven relationships to these logics of power position women differently in this re-imagining.

Understanding how dominant relations of race and class shape women's capabilities to be regarded as 'successful', 'valuable' or 'professional' can decentre liberal concepts like 'work-life balance' (Penny 2015) and clarify how embodied struggles for care within the neoliberal university link to the broader gendered and racialised politics of social reproduction in education and beyond (Rollock, Gillborn and Ball 2014). It also dislodges any romantic belief that a universal autonomous subject existed prior to the neoliberal period of restructuring, illustrating instead that while some women experience the intensified performativity, surveillance, epistemological devaluation and othering appear as 
a rupture, for others these changes are continuities in an institution where certain selves, lives and labour continue to be devalued, policed and invisibilised.

We therefore seek to trouble any universalising perspective of both motherhood and gendered labour in neoliberal institutions by exploring the intersectional experiences of mother-subjects as they appear in, produce and disrupt university space. As Weldon argues, 'marginalized viewpoints are especially valuable for seeing the limits of dominant conceptual schemes because they offer a perspective of social reality that is invisible from the perspective of the dominant group' (2006, pp. 79-80). We are particularly inspired by testimonies of psychological and social 'splitting' and epistemological denial written by women who suffer from intersecting oppressions in universities. Carole Turner (2002), for example, recalls her feelings of anger, frustration and shame when an officer denied her admission to university because he wanted to 'spare' her the failures and disappointments he felt her experiences as a black, labouring-class, single mother would create. And from her position as a border professor, Ana Martinez writes:

I am struck by my lived contradiction: to be a professor is to be an anglo; to be a Latina is not to be an anglo. So how can I be both a Latina and a professor? To be a Latina professor, I conclude, means to be unlike and like me. Que locura! What madness! (Martinez in Turner 2002, 75)

The 'madness' of being denied and impossible - one of the many 'hidden injuries of neoliberal academia' (Gill 2009) - is made public when women problematise or transgress the boundaries between their gendered, classed and racialised roles, or when they overstep the borders of the 'progressive' spaces allocated to them within the establishment. We can speak about motherhood, racism, sexism or our bodies when these are contained as objects 
of academic inquiry. But when women raise these as living problems within academic practice, they become positioned as 'space invaders' who threaten the neoliberal script of professional subjectivity (Puwar 2004; Davidson and Langan 2006; Motta, 2012).

Mothers often face a choice of assimilation or denial in workplaces. The ideal-type mother cannot be an ideal-type neoliberal subject (careless, disembodied and disengaged from the messiness of non-economic life) or an autonomous, flexible 'entrepreneur' of the self. Yet as bell hooks writes, 'assimilation, touted as an answer to racial divisions, is dehumanizing; it requires eradication of one's blackness so that a white self can come into being' (in Turner 2002, p. 20). So it is too assimilating the mother into the academic. This paper examines how feminist academic praxis, in particular the use of dialogical autoethnography, can not only help us to see the gendered, classed and raced workings of capitalist power within the university, but also to deconstruct the paradigms embedded within these logics and to strategically nurture and sustain alternative ways of being in, against and outside it.

\section{Our methodology: From misrepresentation to self-presentation}

Feminist critique clarifies how the norms, time and space of the academic self can exist in contradiction with, and devalue and deny, the mother-self to such an extent that 'mixing motherhood and academia' is regarded as a 'lethal cocktail' in which the 'major losers in academia are women with childcare responsibilities' (Munn-Giddings 1998, 57). However, following Arwen Raddon (2002), we argue that it is precisely in the tensions, cracks and transgressions of these selves - and in speaking about the ways we are classed, racialised and gendered which are often silenced even among ourselves - that we can locate 
resistances to and ruptures of the marketised patriarchal logics of the neoliberal university. In arguing this, we do not seek to rebuild a homogenising universal frame of feminism, 'the mother' or female subjectivity. Rather, as Braidotti (2006) and Motta (2015) suggest, we aim to develop an appreciation of the 'multiple becomings' that can be nurtured from the margins and cracks of feminist agencies and which support the construction of solidarities and alliances of care across difference. Most importantly, we seek new ways of co-creating knowledge which not only helps us analyse the circumstances of our selves, work and intimate lives, but also transforms how we respond to them collectively.

In telling our stories about being and becoming mother-academics, we follow traditions of feminist critique which emphasize the analytical and political importance of seeing from the margins of hegemonic logics and institutions (Anzaldúa 2007; hooks 1994; Motta and Esteves 2014). We focus on sites of life and subjectivities which are often marginalised in critiques of academic labour in order to deepen our understanding and ability to transform the contemporary conditions of labour in, and our relationships to, the neoliberal university. Following critical modes of feminist research which insist that 'the inquirer be placed on the same critical plane as the subject matter' (Tickner 2006, p. 28), we adopt a mode of dialogical auto-ethnographic inquiry that reconfigures research as a pedagogical and prefigurative activity (Motta 2011). This values the research process as a means of creating new and transformative knowledges s as much as - and sometimes more than - it values the results (e.g., in the form of this paper).

The objective of this paper is to problematise our experiences to develop knowledge that is useful for us, other mother-academic subjects and for all who care in our struggles for an inclusive, caring and democratising university. It makes an ethical and epistemological 
commitment to creating a collective reading of our experiences in relation to one another's. To accomplish this, we extend conventional definitions of autoethnography (as the act of systematically analysing...personal experience...in order to understand cultural experience', Ellis et al. 2011) with Jacoby's move from recounting 'experience' to practicing 'self-presentation'. In the latter, 'agents form their own subjectivities and actively present their lives to others' through the dialogical construction of experience with an interlocutor (Jacoby 2006, p. 162).

Such active, dialogical and pedagogical presentations of self and explorations of other do not seek to simply account for or 'share' experience, but to invite witnessing of our presentations of self and to construct new meanings through exploring our attachments to them. This involves deconstructing the individualness of personal experience, honouring and mapping the limits and possibilities of our differential abilities to develop resilience to harmful working conditions, and nurturing relationships in which we disrupt and transgress processes of subjectification by experimenting with alternative processes of becoming.

We enabled this process of inquiry by enacting critical pedagogies of discomfort which, as Megan Boler argues, allow us to 'examine constructed self-images in relation to how one has learned to see others' and to 'recognize how emotions define how and what one chooses to see, and conversely, not to see' $(1999$, p. 176). In this way, we undertook to cocreate a narrative about about how 'our understandings of ourselves and others can... be enhanced by composing our autoethnographies together' (Taylor and Coia 2009, p. 178).

While we have been friends for fifteen years, we sought to experiment with a challenging form of 'alliance-based co-authorship' that would deepen our awareness of how neoliberal 
power articulates differently and that would 'mobilize spaces for both legitimized and hitherto erased (or invisible) critiques to speak with one another, so they can evolve into more nuanced critical interventions in multiple sites' (Nagar 2014, p. 172). What follows is a collaborative reflection on a series of dialogues, recorded over a period of six months in 2012, about our everyday lives and subjectivities as mother-academics, and the hegemonic framings of our experiences which often make them unspeakable. To systematise this process, we recorded and transcribed open-ended, dialogical interviews with one another about our histories and experiences of both motherhood and academic labour. We analysed each interview individually before discussing themes of interest to identify common and diverging concerns. We reflected on these themes, discussing their theoretical, practical and affective significance. Three further periods of interviewing followed in this way, each refining critical matters of shared concern and developing practices for enabling self-presentation and listening to our multiple voices.

Based on a final analysis of the conversations as a whole, we articulated this methodology as a critical alternative to suffering in silence the splitting, denial, and self-discipline that we discovered characterize our experiences as mother-academics in the neoliberal university. As we conducted this inquiry about mothering while mothering - seeking not to 'subtract' our children from our processes of intellectual production but to make explicit its material conditions - our analysis also included consideration of the 'hidden transcripts' of our embodiments and performances as mothers and researchers. We made these visible by transcribing our children's words, needs, emotions and movements into and out of the conversations, and our interactions with them during the interviews (see sample interview timeline below). This technique not only visibilised how caring relations and responsibilities shape flows of knowledge in real time, but also how they can alter the 
value we ascribe to particular moments and ways of knowing. It illustrates why the audited, performative university cannot tolerate an ethic of care; why those who care for others cannot aspire to an individualised, self-determined, 'productive' and entrepreneurial subjectivity; and why socialising relations of care is necessary to advance critical thought which does not deny the multiplicity and wildness of our interrelated selves.

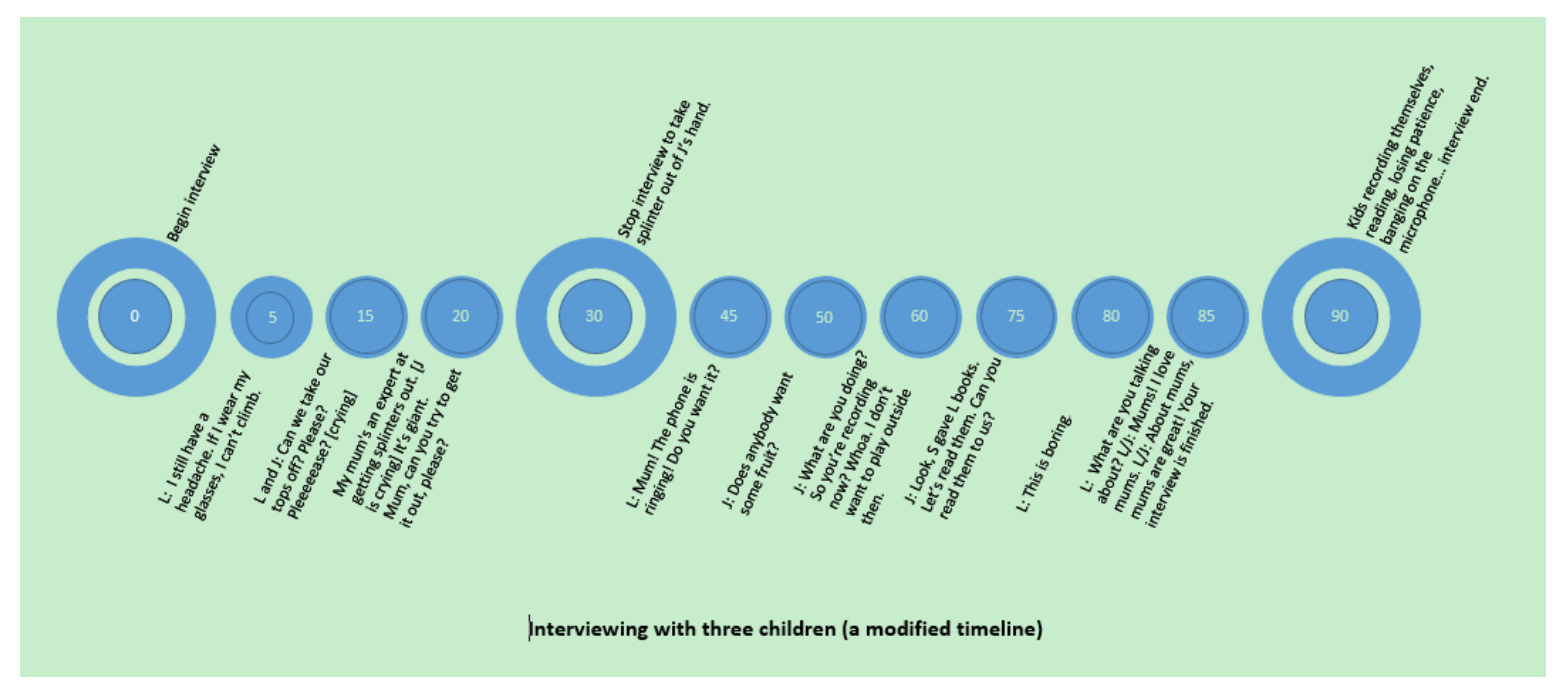

In the following sections, we draw on the data produced through these methods to explore theoretically the madness of splitting, denial, and self-discipline which characterise our experiences as mother-academics in the neoliberal university (and which resonate with findings from other recent research; e.g., Hawkins, Manzi and Ojeda 2014; Mannevuo 2015; Phiri 2014). It is important to note that we explore these themes without bracketing or seeking to reconcile our differences in positionality and experience, and that we foreground considerations of race and class as well as gender in order to clarify the multiple oppressions of disciplinary power. What 'emerges from the interstices of spirit and text' in this exercise is 'a form of reflexive thinking which positions the researcher or writer in dialogue with the many histories that have marked themselves on the body and the context of the interlocutor' (Rowley 2007, 146). 


\section{Neoliberal time and motherhood: always-already potentially producing}

One of the defining characteristics of neoliberal power is that time - particularly 'productive time' - is reduced to an immediatised present without any sense of the multiple imaginaries and collectivities that have existed in the past, or of the possibility of a different future. In this present, we are constantly pushed to speed up with demand which create 'increasingly indefinite divisions between work time and leisure time...[as] work time tends to expand to the entire time of life', thus eroding and marginalising or disciplining the space-time possibilities of other horizons that do not conform to the rhythms of capitalist markets (Hardt and Negri 2005, p. 111; Kenway and Langmead 2000; Mountz et al. 2015). This spatio-temporality also generates ontological and affective gendered violences in which 'feminised' caring relationships of recognition and solidarity are devalued or denied. As Angela McRobbie argues, even the recent resurgence of popular feminisms is contained by a discourse of 'the perfect' which fosters competition amongst women and self-berating about not being good enough. Female subjectivity is interpolated like 'a kind of neoliberal spreadsheet, a constant benchmarking of the self, a highly standardised mode of self-assessment, a calculation of one's assets, a fear of possible losses' (McRobbie 2015, 10; Mannevuo 2015). In the neoliberal university, these practices are woven through the precarity of informal and unregulated working conditions, and through the organisation of time.

Through the process of our inquiry, we learned that we were both 'out of time' as motheracademics but that out-of-timeness manifested itself differently in our experiences. One of us always felt in the wrong place at the wrong time because, as a single parent, she often 
could not divide her time between strongly bounded 'public' and 'private' spaces whose division was constructed as normal in academic life. She therefore ended up being in either an untimely way in university spaces with children, or in untimely absence from formal and informal academic activities when her children needed care elsewhere. Her existence breached the boundaries of temporal propriety from both directions because each relied on unspoken conditions of life that were not hers.

\footnotetext{
It would be fine if I had a wife to look after the kids while I went to a conference; it would all be a normal nuclear bloody family - how do you separate that? My mother-self is completely denied and delegitimised, but there is one [mother-self] that's allowed. (Sara)
}

The other of us was able to embody this permissible mother-self and divide her time between 'public' and 'private' spaces because she was partnered with a person who took responsibility for caring for their child. However, dedicating time to one place often required hardship or denial in the other, and the erosion of self-care and intimate relations. A condition of possibility for such labour was the capacity and willingness to work in careless ways (Lynch 2010).

\footnotetext{
I don't sleep a lot, 4 or 5 hours a night. I can't let go of the need to do things outside the time I actually have. I don't feel like I ever do either thing well enough. I see I'm not there for things or not there attentively with [my daughter] ...there is an expectation that you are permanently working, always 'on-call', permanently, flexible available, both as academics and as mothers. And you just can't be committed and permanently available in both. (Sarah)
} 
We can draw on many examples to illustrate the implications of this 'careless' culture of work for mothers and their children. Consider, for instance, Sara's experience of preparing a proposal for research funding - an 'income generation' activity that is increasingly required as routine for academics across disciplines and stages of career. Whilst expected to compete for scarce resources for research, we are not equally able in material terms to undertake the work required to compete. Yet, the question is rarely asked: What sorts of hidden labour are undertaken, and what invisibilised barriers are encountered and traversed, for someone to arrive at the point from which it is presumed we all begin? What, in other words, are the conditions for the social reproduction of academic labour?

$$
\begin{aligned}
& \text { In order to do [the proposal] I had to spend one term on top of and outside } \\
& \text { normal working hours. This is seen as normal - working } 18 \text { to } 19 \text { hours a day } \\
& \text { and on evenings, weekends and holidays. But it is difficult if you have children, } \\
& \text { and on top of this are their sole carer, and on top of that are in a position of } \\
& \text { financial precarity, and on top of that socially isolated. [...] This meant that the } \\
& \text { process [...] was full of invisibilised barriers. When I brought up not being able } \\
& \text { to eat properly or how I was exhausted, it was not answered to, but if someone } \\
& \text { didn't get back to me about the grant, those concerns were answered to. The } \\
& \text { other stuff was ... seen as an individual problem and considered inappropriate. } \\
& \text { Anything to do with responsibilities or conditions to enable work was seen as } \\
& \text { 'special treatment' rather than equal conditions for labour. They are systematic } \\
& \text { exclusions and inhuman conditions - everyday assumptions about how we are } \\
& \text { supposed to be producing. (Sara) }
\end{aligned}
$$

These experiences illustrate how normalised (gendered and classed) meanings of work, professionalism, spatial and temporal propriety, individual subjectivity and formal equality 
in the academic workplace shape the possibilities a person has to be regarded as a successful subject - and particularly, as Alison Griffith and Dorothy Smith (2005) have illustrated in Mothering for Schooling, to be successful as an educational subject. They are part of a wider politics in which policy and common sense are informed by 'unexamined assumptions that normalise the moral possibilities of middle-class living [in which] the realities of mothering for the working classes are displaced by easy stereotypes and careless, patronising and damaging generalisations' (Vincent, Ball and Braun 2010, p.

136). The criterion for professional worth in this circumstance is the ability and willingness to transgress boundaries between working and non-working time by de-prioritising anything or anyone that impinges upon the first and eliminating the latter altogether. This temporality of academic labour is not only gendered but shaped through intersecting inequalities, unsustainable demands on bodily capacity and dehumanising philosophies of life.

\section{Neoliberal space and motherhood: denial and the madness of splitting}

The disciplining of labour and labouring subjects in neoliberal institutions is also accomplished through the separation and hierarchisation of space, such that relations and responsibilities of care, while fundamental conditions of possibility for being, are relegated to 'hiding' in private space (Mountz et al. 2015, p. 13). The hegemonic space also delegitimizes subjects who are 'other' to the presumed academic subject who either has no caring responsibilities or has these responsibilities taken care of by others. To a great extent, the integrity of this space is premised upon the denial of the mother-self and the madness of splitting. However, such unspoken denial may transform into more active processes of discrimination, de-legitimisation and discipline when mother-academics, out 
of necessity, bring their children into this anesthetised space. The intensification of the divide between public and private space in the neoliberal university thus has particular consequences for academic-mothers. The consequences of this are not homogenous, but differ as impacted by positionalities of race and class as well as by culture, individual and collective history, and normative expectations of the university as an institution. As Sara explained,

as a single parent, [I find] these boundaries are blurred. I have had to bring in the kids (because the nursery's been shut, if they are ill and I have to teach), or I can't be in the space because they are ill and need to be picked up, or I can't afford to get there. The boundaries are blurred by necessity.

Here, the mother-academic and her children disrupt the embodied norms and practices of emotional control through which neoliberal space is performed. This is because

children inevitably create a situation where emotionality and the unruly exist, [as does] that which escapes the boundaries of these really tight bodies who aren't really there in the space. It sort of pushes those boundaries. It brings in life.

In further reflections on the experiences of bringing her children into the university, she said,

I become othered, a problem, [seen as] not behaving professionally, not efficient, not committed, disturbing university space, a threat to health and safety. It was about what is 'proper', and assumes that I was making unreasonable demands. But why would it be read that I am asking for special treatment? This is about 
who I am. Questions of care are excluded from the responsibilities and roles that colleagues have; they are framed as your problems, and as being disruptive or inconsiderate - as not being proper [towards] or nice with colleagues.

Such disruptions place the mother-academic in the position of insider-outsider and 'other'. She becomes subject to informal and formal mechanisms of judgement in which she is misnamed through 'mothering discourse' (Griffith and Smith 2005) as inconsiderate, expecting special treatment, unprofessional and behaving in inappropriate ways. The internalisation of classed, raced and gendered norms of professionalism and the politics of academic space result in practices of judging and being judged, logics of competition between female subjects, and hierarchies of separation (McRobbie 2015). The careless culture of neoliberal university space is thus reproduced in part through a discourse of individualisation, in which relationships are impoverished and structural oppressions become defined as problems of individual failure, lack of consideration or selfishness. This undercuts possibilities of forming solidarities across difference through which we might come to know ourselves and each other and resist anti-ethical and dehumanising conditions. It also creates psychological, emotional and physical dis-ease when those who experience such acts of judgement and denial feel shame, guilt and anxiety for not being 'good enough' and not embodying 'the perfect' (McRobbie 2015). These emotions are corrosive and result in processes of self-disciplining, such that

every day, small things make me feel excluded, shameful, like a problem. I have to hide who I am, my children, my culture [that] is hybrid, whatever that means, the logics who structure who I am. (Sara) 
The nature of university space appears somewhat different through a middle-class lens. Rather than denial or invisibilisation, the dominant themes in Sarah's experience were loss, melancholy and indignation at unmet expectations that a woman is entitled to combine motherhood with an academic profession.

\footnotetext{
It's a kind of melancholy. I think I have a sense of entitlement: why shouldn't I be here? I'm angry about it. My sense is, you've got it wrong, you don't know what it could or should be like, you don't have a wide enough conception of education. For me it doesn't confirm anything [of prior experience]. It's a radical disjuncture from everything I imagined I'd be able to do as a mother and an academic.
}

This disjuncture is not rooted in tensions arising from needing to bring children into university space, but in experiences of 'splitting' between the mother-self and academicself. She continued,
I make life messy for people in other ways, but my being a mother doesn't make it messy. I have a partner, so if I want to bring [my daughter] into spaces I can choose to. For me this is less of a tension, it's an action. Whereas if it was a necessity - if I were to say that I was coming to a committee meeting with a guest because I didn't have any other choice - I suspect it would look a lot different.

The effects of the neoliberalisation of space are felt more palpably when the pressures of neoliberal time make divisions of academic and non-academic dimensions of life untenable. This is particularly problematic when the academic-self colonises the spaces and times of the mother-self, and when there is little consciousness of how a critique which 
'on the one hand blames bad ideologies for women's intimate suffering, while on the other maintains a fidelity to the structures that produced the problems in the first place' limits our imagination of radical alternatives to them (Mannevuo 2015, p. 84). This not only undercuts a woman's ability to mother meaningfully outside of hegemonic framings, but also limits possibilities to create more collective forms of care, intensifies experiences of social isolation, and augments dependencies between partners which create pressures and anxieties in intimate life.

\section{Subjectivation: denial, humiliation and self-disciplining}

The ideal neoliberal subject is infinitely flexible, always on call, de-gendered, de-raced, declassed and careless of themselves and others. The onto-epistemological violence enacted against other ways of being is immense; attempts to erase all practices, imaginings and embodiments of becoming academic differently. For mother-academics are immense, it can create feelings of erasure and denial. For Sara,

\footnotetext{
my ways of being, my logics, why I am in here, what I am, I can't speak it, can't be emotional, can't engage. You're not supposed to be crying, wildly laughing or even to be too theoretical or intellectual. I am almost externalised from myself. I am denied. I deny.
}

Yet our subjectivities as academics can also imbricate smoothly with neoliberal rationalities. Care, too, is infinitely flexible and on call. There is a temptation to engage in practices of care for students and colleagues, as well as those who depend on us, in conditions where such work requires individualised sacrifices or occupies what would otherwise be non-labour time. Our commitments to and ethics of education can be co-opted 
into logics of neoliberal time and space whilst being simultaneously misrecognised and devalued as 'non-academic', feminised activities.

I think part of me buys into the dominant identity of the academic, intellectual, political person. Part of me actually believes that you commit yourself wholly and totally to this work. [...] I'm susceptible to being interpellated by these discourses of flexibility and equality. Teachers who care will work themselves into the ground. Ironically, believing in what I do is precisely what makes me an ideal academic labourer in some ways. (Sarah)

This is not an uncommon irony. As Valerie Hey has argued, an important element of feminist praxis today is that we 'consider our own roles in buying into the particular economy of new times performativity and the rationales we offer about our commitments and performances' (2004, p. 35). In other cases, attempts to survive in conditions of erasure, denial and humiliation result in practices of self-disciplining. For example, Sara said that when bringing her children to work

I feel like I have to hide them by making sure they are quiet, do not leave my office, do not play or cry. In so doing I also hide myself. I do the work of selfdisciplining almost against myself and I enact an emotional and bodily erasure of possibility.

Such experiences can reinforce and confirm feelings of illegitimacy and feeling out of place, resulting in self-judgements that 'I am not the sort of person that should be, or even has a right to be in such a place'. As McRobbie (2015) describes in relation to contemporary young women, but equally applicable here, the neoliberal spreadsheet of self-judgement colonises one's sense of self. 
It is assumed that as academic mother-subjects we can and should want to hide our private lives and be regarded as de-sexualised, de-sensualised and disembodied; this is what is proper and 'serious'. If we are in social spaces after working hours, bringing our children is inappropriate, and of course we do not get drunk or demonstrate desire. In conservative academic environments, women who problematise this norm may be discredited as 'loud, aggressive, hysterical, and demanding' and accused of 'whinging' (Phipps 2006, p. 129). In the university as on the estate,

'when women have children, the demands of respectability expand to include "good" mothering - responsible mothering, providing "appropriate" forms of care. Judgements of failing are levied against both working-class and middle-class mothers; especially, in relation to the latter, in the case of those who are seen as putting career before children.... However, working-class women are particular vulnerable to being judged as failing (Gillies 2006). The label of "bad" mother includes assumptions and judgements of "improper" moral behaviour and inadequate norms of care for and interaction with children' (Vincent, Ball and Braun 2010, p. 127)

We must therefore be modest and 'nice' in meetings as in classroom space, where 'loudness, anger, emotional outbursts, and even something as seemingly innocent as unrestrained laughter [are] deemed unacceptable, vulgar disruptions of... social order' (hooks 1994, p. 179) - even as hyper-sexualised, aggressive and 'laddish' behaviour is normalised on university campuses (Phipps and Young 2015; Jackson and Sundaram 2015). The choice that many mother-academics are faced with, therefore, is to assimilate and be denied, to expend energy on 'pre-empting' misrecognition by developing strategies of performative resistance (Rollock, Gillborn and Ball 2014, p. 107) or to maintain our difference and be judged. 
Yet there is another choice: to speak the unspeakable and embrace our messy otherness as a shout of dignity against this denial. We can learn to become mother-academics otherwise and embrace logics of being, creating, loving, and thinking otherwise in all the spaces of our lives (Motta 2012). Embracing the otherness and marginality of the messiness that motherhood brings to the marketised university takes courage, for it involves emotional risk and exposure to uncertainty. As Nirmal Puwar points out,

in seeking to uncover the institutional narratives and myths that glue professional collectivities, one generates a risky positionality, whereby one is seen to be breaking rank. [...] For space invaders, who never fully belong in the first place, the perils of naming what is ontologically denied in the very being of institutional narratives is even higher. These renegade acts further mark already marked bodies $(2004,138)$

\section{Re-writing the academic: motherhood, resistances and possibilities}

Mothers have powerful roles to play in disrupting the neoliberal academy, making space, time and ways of becoming that open possibilities for an educational praxis and orientation towards work that is both democratising and democratic and that refuses to force our bodies, minds, relationships and spirits into the distorted shapes of neoliberal subjectivity. When women appear in universities as mothers, single mothers and feminists, the demand to negate the needs of self-care and care for others can expose the invisible and unmentionable conditions that make ideal-type forms of neoliberal academic labour possible. Our presence as bodies and selves has the potential to reveal the tacit operations of power that order the dynamics of inclusion, exclusion, (mis)recognition and denial in the institution. It is for this reason that our appearance is so important. 
This is broader than being a mother. It is to do with caring, in terms of human relationships and emotions and the criteria with which we act and treat each other - not competitive, individualistic, survival of the fittest - of being a person who can deny anything other than being producer, performing in certain ways like a disembodied, non-emotional machine that...looks down at everything else as dirty and uncomfortable, messy. When children come in, it is inevitably a situation where the emotionality and the unruly are in the space, all that which escapes the boundaries of these really tight bodies who aren't really there in the space...it sort of pushes those boundaries. (Sara)

Such exposure makes us open to delegitimisation, disciplining and further denial. However, rather than embodying this being other as a form of victimhood with our heads down in shame and bodies contorted in emotional repression, we wish to embrace the epistemic possibilities of these unruly complexities to develop an affirmative critique that opens possibilities to 'author ourselves differently' (Zembylas 2003, p. 125) and to articulate other ways of creating and naming our lives that enable becoming motheracademics differently (Motta 2015).

Embracing this affirmative critique involves not only engaging in critical and dialogical acts of collective self-presentation, but reclaiming and reordering time and space in practice. The architecture of both the university and the subjectivity of the normalised academic is cemented in politically and technologically disciplined logics of space and time that 'corrode character', dehumanise people and relationships, and minimise possibilities for engaging in serious intellectual work (Davies 2005). By creating different rhythms and processes of organising our intellectual and pedagogical practice and everyday lives, we can find ways to resist being subjugated or colonised by these logics 
and to transgress the embodied enactments of neoliberal marketised subjectification (Mountz et al. 2015).

Writing this paper has enabled us to explore how nurturing alternative temporalities, spaces and caring relationships can create conditions for more humanised and feminist forms of academic subjectivity, and for transforming experiences of quiet desperation - as well as habits of striving to conform to impossible norms and expectations through 'endurance, exhaustion and deferral' (Adkins 2015) - into shared narratives of possibility. By creating alternative rhythms - ones that align our intellectual work with the flows of our thinking and dialogue, the blurred boundaries of our public and private lives, the rhythms of our children's experiences and the needs of their and our bodies - we created social, affective and to some extent material conditions in which new subjectivities could emerge. Because this act of collaborative knowledge production was guided by an ethics and politics of care rather than by imperatives of marketised competition or quantitatively measured 'performativity', it also exposed the non-necessary abnormality of neoliberal space-time and subjectivity. We understand now what it takes to build an ethic of care-full slowness in our relationships with one another and with our work, one that honours the time, energy and space that are needed to work ethically in situations of multiplicity and complexity, and which privileges the quality and sustainability of these relationships.

Rather than forcing ourselves to choose between assimilation and denial, or between being 'good mothers' and 'good academics', we choose to affirm alternative ways of being both. To work in this way requires courage to embrace being the othered, the marginal and the outsider and to become more critically aware of how acts of othering, marginalisation and exclusion are oppressing those around us every day. It means that we do not seek acceptance within the dominant frames of value, but rather create alternative ways of 
valuing our academic practice - such as the process of writing this paper - which make it possible to be with its (our) institutional devaluation without regret.

This sort of practice nurtures possibilities for individual and collective refusal. Our refusal to be neoliberal subjects can be enacted through visible, performative ruptures of the normal. But it can also happen in beautiful, painful, transgressive moments when we refuse to allow ourselves and our relationships to be colonised by ethical standards, criteria of value and ways of being and living which are not our own. We have come to realize that while such refusals often happen on the margins of the neoliberal university, they can truly flourish in times and spaces created outside of its institutional logics. This has had deeper consequences than we first imagined, with one of us leaving British academia and both dedicating more time to co-operative learning and knowledge creation within the UK and Australia, respectively. In the end, therefore, this journey of writing ourselves as motheracademics differently has not led us to prioritise strategies of resistance and transformation from within the institution. Rather, it has strengthened awareness that our commitments to an intellectual, affective and political praxis which affirms both being mother and being academic in feminist, humane and sustainable ways can only be realised beyond the marketised logics of the neoliberal university. 


\section{Acknowledgements}

We are grateful for comments on earlier drafts of this paper made by two anonymous reviewers, Claire Polster, Paul Hodge, Lara Daley, Andrew Robinson, Jon Mansell and Siân Adiseshiah, and for opportunities to present drafts at 'Feminism in Academia: An Age of Austerity?' hosted by the Feminist and Women's Studies Association and the Contemporary Women's Writing Association at the University of Nottingham (September 2012) and a seminar at the University of Nottingham Centre for the Study of Social and Global Justice (October 2012).

\section{References}

Acker, S. and Armenti, C. 2004. "Sleepless in academia." Gender and Education 16 (1): $3-24$.

Adkins, L. 2015. “Contingent labour and the re-writing of the sexual contract.” In L. Adkins and M. Denver (eds) The Post-Fordist Sexual Contract: Working and Living in Contingency. Basingstoke: Palgrave Macmillan.

Aisenberg, N. and Harrington, M. 1998 Women of Academe: Outsiders in the Sacred Grove. Cambridge: University of Massachusetts Press.

Amsler, S. 2014. "For a feminist consciousness in the academy." Politics and Culture, Special Issue: Materialist Feminisms against Neoliberalism,' 9 March. http://politicsandculture.org/2014/03/09/for-feminist-consciousness-in-the-academy/. 
Anzaldúa, G. 2007. Borderlands/La Frontera: The New Mestiza. Third edition. San Francisco: Aunt Lute.

Bagihole, B. 1993. 'Survivors in a male preserve: a study of British women academics' experiences and perceptions of discrimination in a UK university." The Journal of Higher Education 26: 176-95.

Bhopal, K. 2015. The Experiences of Black and Minority Ethnic Academics: A Comparative Study of the Unequal Academy. NY: Routledge.

Boler, M. 1999. Feeling Power: Emotions and Education. NY: Routledge.

Braidotti, R. 2006. "Posthuman, all too human: Towards a new process ontology." Theory, Culture \& Society 23 (7-8): 197-208.

Carver. M. H. 2005. "Two truths and a lie: performing professorhood/motherhood." Journal of American Folklore 118 (467): 78-89.

Coate, K. and Howson, C. K. (2014) 'Indicators of esteem: gender and prestige in academic work', British Journal of Sociology of Education, 37(4): 567-585.

David, M. (2004) 'Feminist sociology and feminist knowledges: contributions to higher education pedagogies and professional practices in the knowledge economy', International Studies in Sociology of Education, 14(2): 99-123. 
David, M. (2014) Feminism, Gender and Universities: Politics, Passions and Pedagogies, NY: Routledge.

Davidson, D. and Langan, D. 2006 "The breastfeeding incident: teaching and learning through transgression." Studies in Higher Education 31 (4): 439-52.

http://www.wlu.ca/documents/41635/breastfeeding.pdf.

Davies, B. 2005. "The (im)possibility of intellectual work in neoliberal regimes." Discourse: Studies in the Cultural Politics of Education 26 (1): 1-14.

Donald, A. (2011) 'Levelling the playing field', Impact of Social Sciences, London School of Economics and Political Science, retrieved from http://blogs.lse.ac.uk/impactofsocialsciences/2011/11/07/levelling-the-playing-field/.

Equality and Diversity Advisory Panel (EDAP). 2015. "Equality and diversity in the 2014 Research Excellence Framework: a report by the Equality and Diversity Advisory Panel (EDAP), REF 2014.

http://www.ref.ac.uk/media/ref/content/equal/EDAP\%20final\%20report.pdf.

Equality Challenge Unit (ECU). 2009. "The impact of the process to promote equality and diversity in the Research Assessment Exercise 2008." Research Report. http://www.ecu.ac.uk/wp-content/uploads/external/equality-and-diversity-in-the-researchassessment-exercise-2008.pdf. 
Ellis, C., Adams, T. and Bochner, A. 2011. "Autoethnography: an overview." Forum: Qualitative Social Research 12(1). http://www.qualitativeresearch.net/index.php/fqs/article/view/1589/3095.

European Union. 2012. "Drive to integrate the gender dimension in science." European Commission Research and Innovation News. 21 December. http://ec.europa.eu/research/headlines/news/article_12_12_21_en.html.

Fraser, N. 2009. "Feminism, capitalism and the cunning of history." New Left Review 56 (March-April). http://www.newleftreview.org/A2772.

Gilbert, J. 2008. "Why I feel guilty all the time: performing academic motherhood." Women's Studies in Communication 31 (2): 203-8.

Gill, R. 2009. "Breaking the silence: the hidden injuries of the neoliberal university." In Secrecy and Silence in the Research Process: Feminist Reflections. London: Routledge.

Gillies, V. 2006. "Working class mothers and school life: Exploring the role of emotional capital." Gender and Education, 18 (3): 281-93.

Griffith, A. and Smith, D. (2005) Mothering for Schooling, NY: Routledge.

Haour, A. (2011) 'Unclear REF provisions stand to punish academics who take brief maternity leaves. Researchers should be allowed to submit a reduced number of outputs in line for each period of leave taken.' London School of Economics blog, 9 September, 
http://eprints.lse.ac.uk/52106/1/blogs.lse.ac.uk-

Unclear_REF_provisions_stand_to_punish_academics_who_take_brief_maternity_leaves

$\underline{\text { Researchers_should_b.pdf. }}$

Hardt, M. and Negri, A. 2005. Multitude: War and Democracy in the Age of Empire. NY:

Penguin Press.

Hawkins, R., Manzi, M. and Ojeda, D. 2014. "Lives in the making: power, academia and the everyday." ACME: An International e-Journal for Critical Geographies 13 (2): 328 51.

hooks, b. 1994. Teaching to Transgress: Education as the Practice of Freedom. NY:

Routledge.

Jackson, C. and Sundaram, V. (2015) 'Is "lad culture" a problem in higher education?

Exploring the perspectives of staff working in UK universities', final report, Society for Research into Higher Education,

https://www.srhe.ac.uk/downloads/JacksonSundaramLadCulture.pdf.

Jacoby, T. 2006. "From the trenches: dilemmas of feminist IR fieldwork." In Ackerly, B., Stern, M. and True, J. (eds) Feminist Methodologies for International Relations.

Cambridge: Cambridge University Press.

Jaschik, S. 2008. “"Quiet desperation’ of academic women.” Inside Higher Ed. 12 June. http://www.insidehighered.com/news/2008/06/12/women. 
Jenkins, F. 2014. "Episetmic credibility and women in philosophy." Australian Feminist Review 29 (80): 161-70.

Jump, P. 2011. "Pregnant pause results in less labour for REF." Times Higher Education. 3 November. https://www.timeshighereducation.co.uk/news/pregnant-pause-results-in-lesslabour-for-ref/418029.article.

Kenway, J. and Langmead, D. 2000. "Fast capitalism, fast feminism and some fast food for thought." In S. Ali, K. Coate and W. Goro (eds) Global Feminist Politics: Identities in a Changing World. London: Routledge.

Klocker, N. and Drozdzewski, D. 2012. "Survival and subversion in the neoliberal university." Response to the Participatory Geographies Research Group's "Communifesto for Fuller Geographies towards Mutual Security.” http://ro.uow.edu.au/smhpapers/1184/.

Klocker, N. and Drozdzewski, D. 2014. "Commentary: career progress relative to opportunity: how many papers is a baby 'worth'?” Environment and Planning A 44: 127177.

Leonard, P. and Malina, D. 1994. "Caught between two worlds: mothers as academics." In S. Davies, C. Lubelska and J. Quinn (eds) Changing the Subject: Women in Higher Education. NY: Taylor and Francis. 
Lynch, K. 2010. “Carelessness: A hidden doxa of higher education.” Arts and Humanities in Higher Education 9 (1): 54-67.

Mannevuo, M. (2015) "Caught in a bad romance? Affective attachments in contemporary academia." In L. Adkins and M. Denver (eds) The Post-Fordist Sexual Contract: Working and Living in Contingency. Basingstoke: Palgrave Macmillan.

McRobbie, A. 2009. The Aftermath of Feminism: Gender, Culture and Social Change. NY: Routledge.

McRobbie, A. 2015. "Notes on the perfect." Australian Feminist Studies 30 (83): 3-20.

Mills, D. and Berg, M. 2010. “Gender, disembodiment and vocation: exploring the unmentionables of British academic life.” Critique of Anthropology 30: 331-53.

Motta, S. C. 2011 "Notes Towards Prefigurative Epistemologoies.” In S. C. Motta and A. G. Nilsen (eds) Social Movements in the Global South: Development, Dispossesion and Resistance. London/NY: Palgrave Macmillan.

Motta, S. C. 2012. "The messiness of motherhood in the marketised university." Beautiful Transgressions, Ceasefire. 12 June. https://ceasefiremagazine.co.uk/messinessmotherhood-marketised-university/. 
Motta, S. C. 2015. "Becoming woman: exile and belonging to the borderlands." In Z. Arashiro and M. Barahona (eds) Women in Academia Crossing North-South Borders: Gender, Race and Displacement. NY: Rowman and Littlefield.

Motta, S. C. and Esteves, A. M. 2014. "Reinventing emancipation in the 21st century: the pedagogical practices of social movements." Interface: A Journal for and about Social Movements 6(1): 1-24.

Mountz, A., Bonds, A., Mansfield, B., Loyd, J., Hyndman, J., Walton-Roberts, M., Basu, R., Whitson, R., Hawkins, R., Hamilton, T., Curran, W. 2015 "For slow scholarship: a feminist politics of resistance through collective action in the neoliberal university." ACME: An International E-Journal for Critical Geographies. In Press.

https://www.academia.edu/12192676/For_Slow_Scholarship_A_Feminist_Politics_of_Res istance_through_Collective_Action_in_the_Neoliberal_University.

Munn-Giddings, C. 1998. "Mixing motherhood and academia: a lethal cocktail.” In D. Malina and S. Maslin-Prothero (eds) Surviving the Academy: Feminist Perspectives. NY: Routledge.

Nagar, R. (2014) "Four truths of storytelling and coauthorship in feminist alliance work." In Muddying the Waters: Coauthoring Feminisms across Scholarship and Activism.

Chicago: University of Illinois Press.

Newman, J. 2013. "Spaces of power: feminism, neoliberalism and gendered labor." Social Politics, 20(2): 200-221. 
Ng, R. 1997. "A woman out of control: deconstructing sexism and racism in the university." In J. Glazer-Raymo, B. Townsend, and B. Ropers-Huliman (eds) Women in Higher Education: A Feminist Perspective. Boston: Pearson.

Penny, L. (2015) 'Women can't have it all - because the game is rigged', 26 October, New Statesman, http://www.newstatesman.com/politics/feminism/2015/10/women-can-t-haveit-all-because-game-rigged.

Pereira, Maria do Mar. 2012. "Feminist theory is proper knowledge, but...The status of feminist scholarship in the academy." Feminist Theory 13(3): 283-303.

Phipps, A. (2006) “"I can’t do with whinging women!” Feminism and the habitus of “women in science” activists', Women's Studies International Forum, 29: 125-135.

Phipps, A. and Young, I. (2015) 'Neoliberalisation and "lad cultures" in higher education', Sociology, 49(2): 305-322.

Phiri, A. 2014. "Critical spaces: processes of othering in British institutions of higher education." Journal of Feminist Scholarship 7/8. http://www.jfsonline.org/issue78/articles/phiri/.

Pugh, E. 2011. "Maternity leave and the REF." Equality Challenge Unit press release. 28 October. http://www.ecu.ac.uk/news/maternity-leave-and-the-ref/?searchterm=REF.

Puwar, N. 2004. Space Invaders: Race, Gender and Bodies Out of Place. NY: Berg. 
Raddon, A. 2002. "Mothers in the academy: positioned and positioning within discourses of the 'successful academic' and the 'good mother'." Studies in Higher Education 27 (4): 387-03.

Reay, D., Crozier, G. and Clayton, J. (2009) '"Fitting in" or "standing out": working-class students in UK higher education', British Educational Research Journal, iFirst article: 118.

Reay, D., Davies, J., David, M. and Ball, S. (2001) 'Choices of degree or degrees of choice? Class, 'race' and the higher education choice process', Sociology, 35: 855-874.

Research Excellence Framework (REF). 2014. “All FAQs about the Research Excellence Framework." http://www.ref.ac.uk/about/guidance/faq/all/.

Rollock, N., Gillborn, D., Vincent, C. and Ball, S. J. (2014) The Colour of Class: The Educational Strategies of the Black Middle Classes, NY: Routledge.

Rowley, M. 2007. "Rethinking interdisciplinarity: meditations on the sacred possibilities of an erotic feminist pedagogy." Small Axe (October): 139-53.

Shilliam, R. 2015. "Black academia: the doors have been opened but the architecture remains the same.” In Alexander, C. and Arday, J. (eds) Aiming Higher Race, Inequality and Diversity in the Academy. London: Runnymead Perspectives. http://www.runnymedetrust.org/uploads/Aiming\%20Higher.pdf. 
Stromquist, N. (2015) Review of M. David, Feminism, Gender and Universities: Politics, Passion and Pedagogies in Gender and Education, 27(3): 359-360.

Taylor, M. and Coia, L. 2009. "Co/autoethnography: investigating teachers in relation.” In Lassonde, C., Galman, S. and Kosnik, C. (eds) Self-study Research Methodologies for Teacher Educators. Rotterdam: Sense Publishers.

Tickner, J. A. 2006. "Feminism meets International Relations: some methodological issues.” In Ackerly, B., Stern, M. and True, J. (eds) Feminist Methodologies for International Relations. Cambridge: Cambridge University Press.

Turner, C. S. V. 2002. "Women of color in academe: Living with multiple marginality." The Journal of Higher Education 73 (1): 74-93.

Turner, C. S. V., González, J. C. and Wong (Lau), K. 2011. "Faculty women of color: The critical nexus of race and gender." Journal of Diversity in Higher Education 4 (4): 199211.

University and College Union (2006) 'Guidance on RAE 2008', retrieved from http://www.ucu.org.uk/media/pdf/2/p/ucu_rae2008guidance_1.pdf.

Vincent, C., Ball, S. J. and Braun, A. (2010) 'Between the estate and the state: struggling to be a "good" mother', British Journal of Sociology of Education, 31(2): 123-138. 
Weldon, S. L. 2006. "Inclusion and understanding: a collective methodology for feminist International Relations.” In Ackerly, B., Stern, M. and True, J. (eds) Feminist Methodologies for International Relations. Cambridge: Cambridge University Press.

Wolfinger, N., Mason, M. A. and Goulden, M. 2008. "Problems in the pipeline: gender, marriage and fertility in the Ivory Tower." Journal of Higher Education 79 (4): 388-405.

Zembylas, M. 2003. “Interrogating 'teacher identity’: emotion, resistance and selfformation." Educational Theory 53 (1): 107-27.

\section{Notes}

${ }^{1}$ A similar discussion has emerged in Australia from a team of mother-academic geographers who asked 'how many papers is a baby 'worth?' to explore the gendered implications of disciplinary norms under the neoliberal regime of calculative excellence (Klocker and Drozdzewski 2014).

${ }^{2}$ In 2011, the Higher Education Funding Council of England (HEFCE) undertook a consultation to determine how caring relationships should be accounted for in judgements about the quality of academic work in the 2014 Research Excellence Framework (REF). HEFCE had been criticised for penalising women during the 2001 research exercise by offering no allowances for maternity leave at all, and in 2008 for defining it as an ‘extenuating circumstance' (Donald 2011; UCU 2006). In 2011, HEFCE recommended that women who took fourteen months of maternity leave during the six-year study period 
should be permitted to submit one less piece of work. Criticism from across the sector eventually led to the removal of this time limitation.

${ }^{3}$ This was described by one critic as 'vastly fairer' as it took 'appropriate consideration of maternity leave without adding complexity' (Jump 2011).

${ }^{4}$ Our critique intersects with discussion in feminist epistemology about the nature of feminist critique, in particular 'its ways of inheriting or rejecting disciplinary norms, and how that then locates it as a project in relation to academic disciplinarity', including through misrecognition as a 'non-academic' activity (Jenkins 2014; Pereira 2012). 